\title{
Through the Closet: Private Devotion and the Shaping of Female Subjectivity in the Religious Recess
}

SUSAN

COMILANG

Résumé : Des écrivaines et femmes devotes qui vivaient en Grande-Bretagne au dix-septième siècle nous ont légué des textes qui expriment leur conception de Dieu et leurs désirs et qui donnent forme à la perception que les femmes avaient d'elles-mêmes. Dans les écrits de An Collins, de Dame Gertrude More et de l'auteur anonyme de Eliza's Babes, les femmes ne se considèrent pas comme des êtres passifs, mais comme des théologiennes, des femmes de Dieu et des esprits éclairés. La psychanalyse lacanienne nous aide à comprendre leurs travaux et nous oriente vers une conception différente du désir et de la femme, cette dernière étant consciente à la fois de fragmentation et de complétude.

Tn Ancillia Pietatis: or, the hand-maid to private devotion (1633), a guide dedicated to the Duchess of Buckingham and presented to her as a "servant to attend you in your closet,"1 Daniel Featley draws an intriguing image:

For private Devotion (to shunne ostentation and Hypocrisie in heavenly things) alwaies shuts her selfe up in her closet, desiring no eye to see her but her Father's in secret. Wounded shee is (like the Spouse in the Canticles) with the darts of divine love; and continually bleedeth, but inwardly in teares of compassion, compunction, and excessive joy. There appeares no externall orifez in the flesh to be seene. She resembles the strange plant in Plinie, which buds inwardly, and shooteth forth no bud, blossome, or leaf outwardly. For if private Devotion cometh once to be knowne, it ceaseth to be private. ${ }^{2}$

Featley has gendered private devotion as female-possibly in tribute to the Duchess-in a preface that is full of contradictions. It was not common in seventeenth-century England to allegorize private devotion as 
a female figure, but Featley's image taps into many of the characteristics of the ideal early modern woman: she does not seek outward attention, she keeps herself separate from others, she exists chastely, and she is either a daughter or a wife. Peter Stallybrass describes the ideal "Woman" of the ruling elite as "like Bakhtin's classical body ... rigidly 'finished': her signs are the enclosed body, the closed mouth, the locked house."3 A woman who lacked these characteristics in the early modern period was known, according to Gail Kern Paster, as a "leaky vessel."4 Featley refers to the uncontrolled flows of the female body-blood and tears-and hopes to keep them contained. His ideal of private devotion has flesh without any "externall orifez;" it is a closed and sealed vessel, much like the bodies of saints. 5

To illustrate this seamless flesh, Featley cites the plant in Pliny's Natural History, most likely the burdock which Pliny calls remarkable because "within it there grows a flower that does not show, but is inside and hidden; it produces seed within itself, as do the animals that bring to birth inside their own bodies."6 Featley modifies the image of gestation and birth: the product of private devotion, according to Featley, is not a baby but a sincere religious devout. A woman's private devotion contains complaints, vows, confession, repentance, "the soules discipline mentioned by Saint Paul [which] are most necessary exercises of religion, yet cannot bee so safely done, nor so decently, nor so effectually in publike as in private."7 Private devotion belongs to the secret and recessed.

Given the hidden nature of private devotion, can this space be mapped and analyzed? Do female religious devouts also remain hidden, especially when allegorized as private devotion? Are they lost in the liminal movement between known and unknown, the private and the public? Not many women ventured into public ministry in the early modern period, but the works and discipline of private devotion have left traces, especially in the conceptualization of the soul in private, or what George Herbert calls the "soul in paraphrase." ${ }^{8}$ Female devotional writers and practitioners have left us their texts which give word to their desires and understandings of God, and shape the construction of privacy and the self.

Three devotional writers - the anonymous author of Eliza's Babes, An Collins, and Dame Gertrude More-offer a textual overview of material practices and objects, lived relationships, representations of interiority, and ideas of the female which circulated in and constructed private devotion. Eliza's Babes; or the Virgins-Offering (1652) is an anonymous work which has recently begun to receive critical attention. A line on the title page states that the poems and prose meditations were "[w]ritten by a Lady, who onely desires to advance the glory of God, and not her own." (For the purposes 
of this essay, the author will be referred to as "Eliza," which is how the persona references herself). An Collins's Divine Songs and Meditacions (1653) was printed once in the seventeenth century, and from this printing only one copy survives as part of the Huntington Library's collection. ${ }^{10}$ Her opening poem, "The Discourse", may be considered a theological tract. The Spiritual Exercises of the Most Vertuous and Religious D. Gertrude More (1658) by Dame Gerturde More, a granddaughter of Sir Thomas More, was published in Paris after her death. Her text consists mainly of meditative prose passages with poems scattered among them.

The examination of these female poets enters into a mapping of the space of private devotion begun by Richard Rambuss in Closet Devotions. One of Rambuss's aims is "to put forth the subjectifying apparatus of the prayer closet, and the culture of private devotion it comes to represent, as a node for another chapter in the history of the self and its passions taken up in medias res by Foucault at the Counter-Reformation confessional."11 For Rambuss, "[c]loset devotion, in other words, is the technology by which the soul becomes a subject." 12 Rambuss is primarily concerned with male desire and the prayer closet. I am interested in female private devotion, which may take place in a prayer closet, but which also reaches more widely to include the practices and mental states of private devotion as they occur in a number of Catholic and Protestant representations. These representations of private devotion can be categorized under the term "religious recess." The term allows for a broad range of spaces, from closets to entire houses when they are used as Catholic safe houses. Infusing the material space of devotion were concepts of privacy, gender, and the self. My essay concentrates on the female self who constructed the site of private devotion and in turn was constructed by it.

Private and public were fluid terms in the early modern period, even when describing household space, and all the more so with respect to aristocratic devotions. ${ }^{13}$ For women, privacy was joined with the ordinary perils of being female: inconstancy, licentiousness, misrule. Although both men and women withdrew for meditation, Bible study, prayer, and self-examination, the woman in withdrawal had to contend with being commodified as a governable, spatial body. In other words, her desire for devotion could be elided by another's need to control her; to control her privacy and what she did within it. The woman and the space become one and the same. As Georgianna Ziegler argues, "the woman's chamber has represented her 'self': both her physical body and mental/spiritual nature."14 Woman embodied private property for men. As a spatial entity a woman was to be contained and controlled in where she went, whom she saw, and what she did. The continuation of patriarchy insists on the commoditization of 
woman as wife, daughter, or sister. ${ }^{15}$ As Ziegler notes, women of the early modern period were instructed to keep their private spaces chaste, separate, and intact from others' entrances, or face the consequences, which often amounted to the destruction of self.

Contradictions in the concept of privacy in the early modern period-especially as it relates to women-can be found in the works of Featley (as shown above) and Richard Braithwait. Braithwait discusses private devotion under a section entitled "Behaviour" in The English Gentlewoman (1631). He warns his female readers that

be you in your Chamber or private Closets; be you retired from the eyes of men; thinke how the eyes of God are on you. Do not say the walls encompasse mee, the darknesse o'ershadows mee, the Curtaine of night receives me : these be the words of an Adulteresse: therefore doe nothing privately, which you would not do publikely. ${ }^{16}$

Braithwait sees a danger in privacy that women must guard against. God's eye acts much like a warden to make sure that women do not commit indiscretions. Braithwait here differs from Featley, who sees privacy as a positive space for the devout. Braithwait wants to agree, but his fears prevail and he inverts the idea of the closet as a space unlike the theater to an idea of it as a private theater:

Enter your Chambers and be still. Still, and yet stirring still. Still from the clamours and turbulent insults of the World; still from the mutinous motions, and innovations of the flesh. But neuer still from warring, wrastling, bickring and embattailing with the Leader of those treacherous associats . . . Make then your Chamber your priuate Theatre, wherein you may act some deuout Scene to Gods honour. Be still from the world, but stirring towards God. ${ }^{17}$

The female devout thus participates inwardly in a scene where the privacy of the closet becomes an enclosed theater with God as audience and the devout as actor. Enclosure is what ties Braithwait's and Featley's conceptions of private devotion together. However, Braithwait constructs devotion as a series of fights, a war against the unholy trinity: the world, the flesh, and the devil. With so much at stake, the female self in devotion is always under scrupulous observation, even in private.

The imaging of private devotion as a theater works to dissolve the boundaries between public and private. The woman's outward stillness to the world may create a recessed withdrawal, but her inward activities are not entirely solitary. They are scripted devotional acts which regulate a woman's privacy, preventing her possible "misrule" and disrobing female devotion of any inwardness that cannot be known and governed. Private 
devotion involves inventing both a proper self and a divine other: if in Featley's view private devotion produces the sincere devout, in Braithwait's it produces the seemingly sincere female devout, or at least the best that one can get from such a duplicitous nature as woman's.

Private devotion was thus problematic in different ways for women than for men: female private space was equated with chastity, and the woman's devotional privacy was deemed less important than the maintenance of her chastity. Despite these complications, women found in the religious recess a space to voice their desires to themselves and others. They image themselves not as passive vessels or scripted actors but, as we shall see in the texts examined below, as theologians, brides of Christ, and sound minds. Their investment in private devotion even led the way, in some cases, to public devotion, whether it was through charity, circulation of their devotional writings, or the opening of their homes to further their ministry.

The devotional writings of More, Collins, and Eliza moved representations of private devotion and female occupants into the public sphere. These representations fall across the spectrum of religious beliefs in early modern England. More is the most readily categorized. She was a nun of a Benedictine order, a woman who retreated to the Continent in order to follow her vocation. Her work, as argued by Dorothy Latz, is part of a mystical tradition which draws upon both English and Continental sources. ${ }^{18}$ Collins and Eliza fall in the Protestant range, but it can be difficult to determine exactly where. Collins may be considered an Anglican royalist. Her Anglicanism, however, is dominated by the terms of Calvinism. Others have read her as one who might even be a sectarian. ${ }^{19}$ Eliza has also been associated with Independents and Baptists, but as L.E. Semler points out, "Eliza's Babes seems to locate itself between Sibbes and Hobson, between non-separatist puritan and sectarian enthusiast, enjoying the reformed doctrinal stability of the former, the affective freedom of the latter, and the sincere Canticles-inspired experimentalism of both." 20

These poets bring the reader into contact with conceptualizations of withdrawal, the self, and devotion. Their texts record the movements of desire and bespeak the female devout's relationship to God and others. Desire breathes the female subject into existence; she seeks God through a voracious and compelling longing channeled through a communion of prayers, meditation, reading, and self-examination. Later, I will discuss these poets in the context of Lacanian psychoanalysis, to show how it both helps our understanding of their work and points to a different idea of self and desire. 
Unlike Braithwaite's image, the three poets do not form themselves in contrast to a demonic Other; they are not continually at war; they do not live under the eyes of a suspicious God. The main relationship is one of communion between the beloved and the Lover God. The religious recess becomes what Foucault calls a "heterotopia." These spaces are "counter-sites, a kind of effectively enacted utopia in which the real sites, all the other real sites that can be found within the culture, are simultaneously represented, contested, and inverted." 21 In spite of the more negative prescriptions given to women, women in private devotion found a space of agency. Through their devotional practices and the production of poetry from and for private devotion, these three poets constructed and conceptualized heterotopic spaces. They were indeed souls in paraphrase whose writings allow us to see the shape of devotional desire in space and subject.

There are some similarities of theme and image in the selves and sites that Eliza, Moore, and Collins delineate. God is likened to the sun; divine grace appears as streams to purify the soul; the presence of God is a ravishing delight. Each writer also confronts the physical disparity and spiritual corruption between heaven and earth, the Divine Lover and the female devout. While differences occur in their portrayals of the mystical union, the communion between God and devout is the prism through which each sees and knows self and other. The differences that do appear may stem from the different Protestant and Catholic traditions. ${ }^{22}$

All three writers use the common trope of courtship and marriage. Their depictions of the physical body of the Divine Lover differ in degree and somewhat in type from those of male devotional poets, such as Donne and Herbert. For the male poet, the relationship figured between Christ and man is much more corporeal. ${ }^{23}$ Michael Schoenfeldt says of Herbert that he found "in sexual union and sensual pleasure a compelling model for the intimacy between humanity and God signaled by the incarnation, and celebrated in the Eucharist." 24 Schoenfeldt reads Herbert's "Love (III)" as discomforting the reader because the "eroticism is at once more delicate and more deeply engrained in the divine." 25 Sacred poetry adopts and adapts Petrarchan motifs for the body of Christ, which like the body of the beloved has admired physical attributes. ${ }^{26}$ These may be extolled in a blazon or, as Schoenfeldt describes the action of Christ's kenosis in Herbert's "The Bag," as a "kind of cosmic striptease."27

By comparison, Eliza, Collins, and More set the body of Christ at more of a distance. Eliza in "The Lover" has a slight blazon where she compliments Christ as being the "purest red and white" (9) and praises his hair, face, and eyes. Collins and More also desire God, but his physical attributes do not figure much in their poetry. They focus more upon his non-physical 
attributes. Collins writes, "What hath been sayd of God shall now suffice, / Of whom I frame no Image in my mind, / But I conceive him by his properties" ("The Discourse," 229-31). More, blinded by the "dazzling looks" of Christ, kisses him with "blindfaith." Either she will not or cannot elaborate on these looks. This reluctance to speak about the beloved's body is most likely due to the societal mores for women in the early modern period and, for Protestants, to Reformation iconoclasm. In a similar manner, Lady Mary Wroth in her secular sonnets, Pamphillia to Amphilanthus, does not physically objectify the male beloved, and the sonnets attributed to Mary, Queen of Scots, also do not describe the male love object.

Even without an eroticized physical body, desire moves through these women's verses and works to construct identity. Lacanian psychoanalytic thought can partially map this desire and the self it produces. In the Lacanian construct, the self gains a subject position in the symbolic realm through language. This entrance into the symbolic involves the introduction of a third term, such as the father to the mother-child dyad, to promote difference and distinction. ${ }^{28}$ The subject must submit to what both Freud and Lacan term the name-of-the-father. In the oedipal phase, in differing ways as male or female, children must reject the mother and accept the law-of-the-father. Part of this rejection stems from the threat of castration, particularly for boys. Their conforming to the law gives them, as Elizabeth Grosz explains, a position, "a place as a subject in culture. The child becomes a subject only with reference to the name-of-the-father and the sacrificed absent body of the mother." 29

This Lacanian construct resembles a pattern found in Christian theology, with differences: the sinner enters the community of faith by assuming the name-of-the-father, through the sacrificed body of Christ. The triad necessary to create meaning in language occurs in theology through the power dynamics of the sinner and salvation. Christian theology does not stage a rejection of the mother, but rather a rejection of the world of sin. The triangulation of terms lies not so much in the familial unit of mother, father, and child as it does in the pull of the sinful earth, the sinner, and the Passionate God. This is God as Father, God as bridegroom or Lover, God as sacrificial Lamb, or God as Love itself, who in these many guises has female characteristics. What threatens the sinner is not a new fragmentation, as in the castration threat, but rather a continued fragmentation of self as the sinner remains separated from God, forever in sin and never whole.

Both male and female religious devouts reject sin in favor of God. The Christian tradition has often stigmatized the female body as the symbol of the sinful earth and/or sin, the flesh which divides the soul from the divine. In the writings of the three poets studied here, this stigma has been 
rewritten. Here, the body of sin is not equated with the female body. The triad of the world, the flesh, and the devil - where women play the negative role of the flesh-becomes recast as the drama of the devout, sin, and the Divine Lover. These writers also do not automatically link the rejection of sin to images of the mother or the feminine. They reject sin, vanities, and earthly temptations. The authority of male figures is held subordinate to God's authority, which women had the power to know and reflect.

The desire of these three women writers is for fusion and an organic belonging which would join sinner to God, changing the position of the sinner to one of the saved, or, as the puritans phrased it, the elect. This fusion must begin from difference, noticing the blemishes and fragmentation caused by sin, and move to sameness as the female sinner assumes the name-of-the-father, the law which theology reworks and rewords through grace in the sacrificed body of Christ. Yet, difference remains in the individuality of each singular subject in her relationship with God. The Lacanian construct of desire and its figuring of lack as the motivator for the obtainment of the Other again has similarities to what theology maps. However, the "lack" driving the devout does not find satiation in object after object. Its fulfillment is met by one object, the Divine Other. The Divine Other gives the female devout a subject position from which to speak and a person to whom she relates. For instance, in "Christ's Kingdom," Eliza states:

\author{
When thou hast cast off that foule sin, \\ Thy kingdom in me didst begin \\ And here thou wilt still reign in me, \\ Till I shall come and reigne with thee (13-16)
}

Communion confounds the disparity of time and space. Eliza locates God and his kingdom within her until they will physically be brought together. Unlike Lacanian desire, hers does not seek object after object in a never-ending and ultimately incomplete search for fulfillment. Instead, the female devout finds satisfaction in her communion with God, the Divine Other. Collins asserts this in "A Song manifesting / The Saints eternall Happinesse":

\author{
Also they have \\ (Their joy to amplify) \\ Immediat sweet communion with \\ The blessed Trinity. \\ Which satisfies the appetite, \\ Which else were empty still, \\ Because no finite comfort can
}

Content the mind and will (89-96). 
Additionally, the three writers understand language or the "word" to have a fixed relationship with a signified. This fixity, however, only occurs when the word is infused with the grace, spirit, or love of the Divine Other. For example, Collins writes in "The Discourse," "His word doth take when grace shall have possession, / For by the word no good efect is wrought / But where the heart is by Gods spirit taught" (348-350). Therefore, the devout experiences the fullness of language even as she realizes its failure to express entirely what she means. More writes, "Yea if I writ out all the sea, /yet could I not expresse / The joy and comfort I do feele / In what thou dost possesse" ("Our Hearts are Restless," 145-148).

Thus "lack" in its psychoanalytic sense does not quite correlate with what the female devout experiences and expresses. Instead of a subject split by the bar of repression, the self understands a duality of location united through a desire for the God who exists in both. The subject produced by the Other in private devotion is analogous to what Aemilia Lanyer calls Christ, "a union of contraries," 30 a paradox of division where either/or becomes both/and. The female devout is both sinner and saint. She has an insatiable desire for the Other which cannot be filled, yet is. She is both cognizant of fragmentation and aware of wholeness. The theology of desire produces a fragmented and whole self while on earth. This self at once longs for God while existing whole in God in an intersecting site of heaven and earth found in private devotion.

The site, or rather sites, produced by the communion between Divine Other and devout have a different emphasis in each of the three writers. Collins focuses upon God as a "rock" and "shelter" as her poetry charts the movements of the soul sustained through "lively faith," even if there are moments when the soul is "benummed." Eliza's Babes uses the metaphor of marriage as a representation of puritan self-examination, as proposed by John Preston in The Mystical Match. ${ }^{31}$ Her work bustles with the everyday brought into the presence of the sacred, as heaven is conjoined to the earthly. More focuses upon the absorption and dissimulation of self into the river of Love.

In Collins's theological explication of the relationship between devout and God, Christ's sacrifice can free all, but not all have the faith which saves the sinner. Once grace has been given to the sinner, who through the seeds of faith desires forgiveness and reconciliation, God

... as he hath promised, will prove

Propicious to the sinner penitent,

And let him feel th'assurance of his Love,

His Favour, Grace, and Mercy Excellent

The which in Christ, appears most emminent: 
A lively Faith this full assurance is,

Wrought by God's Spirit, in the hearts of his ("The Discourse," 519-25).

This "lively faith" for the elect underlies and shapes the experience of self. In union with God, the devout has rest, joys, safety, and "all good." Nonetheless, the devout will still experience despair, sorrow, pain, and temptation, even as she is assured of salvation. Trials serve to strengthen the devout and remind her of the enduring union she has with God. As Collins points out in "A song exciting to spirituall Alacrity":

Discomforts will the heart contract

And joy will cause it to dilate;

That every part its part may act,

A heart enlarg'd must animate (1-4).

Tested and tried, the self in faith emerges as a "sound mind," a mind which has a positive effect on the afflicted body and the trials the soul endures. The mind is the site and product of fulfilled desire in God. For example, in "A Song expressing their happinesse who / have Communion with Christ," she writes

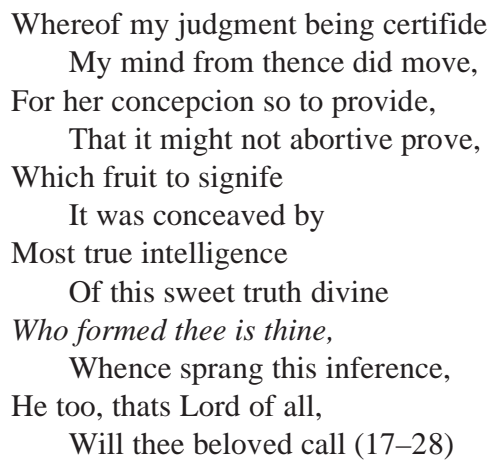

The desired relationship with God produces knowledge, a mind that can conceive "true intelligence," and a self beloved of God. The knowledge comes from meeting with God, for "[n]ow when we feel Gods favour / And the communion with him we have, / Alone we may admit of joy / As having found what most we crave" ("A Song shewing the Mercies of God to his / people ..." 41-44). Private devotion gives a space and time for this joy, even if the space is more a state of mind then a physical reality. The desire to be with God also produces a mind not hysterical or unwise, but one that Collins proclaims in "A song manifesting / the Saints eternall Happinesse" to be sound: "Sound is the minde / Which doth that Hope possesse / Whose object is Eternall joy / Or Heavens happinesse" (1-4). 
The tone of Collins's poetry is one of tender seriousness. Only rarely does she break out in ecstatic moments where she uses words similar to other devouts who feel delight in their mental and sensory relationship with God. For instance, she finds "[t]he Contemplacion of his mercies sweet, / Hath ravished my Soule with such delight" ("The second Meditacion," 7-8). Still, this ravishment is not the same as the battering Donne receives and calls for in his sacred sonnets. Collins experiences the "firme fruition / Of his Sweet presence" ("A Song expressing their happiness ..." 82-83) and extols the sweetness of God. What Collins finds most delight in is the knowledge of God as rock, shade, and shelter for her. Though the world may provide tribulations, the devout knows God will be present. This knowledge may become shadowed by a momentary lapse of feeling or despair, but the soul wrought in faith (re)turns to find God present.

Perhaps this is why Collins, in "A Song expressing their happinesse / who have Communion with Christ", rewrites a set piece of the Canticles, The Songs of Songs, to show how sin can make the soul think she has no help. The Lover's call to the Beloved acts as a reminder of what occurs when the soul can see only what seems:

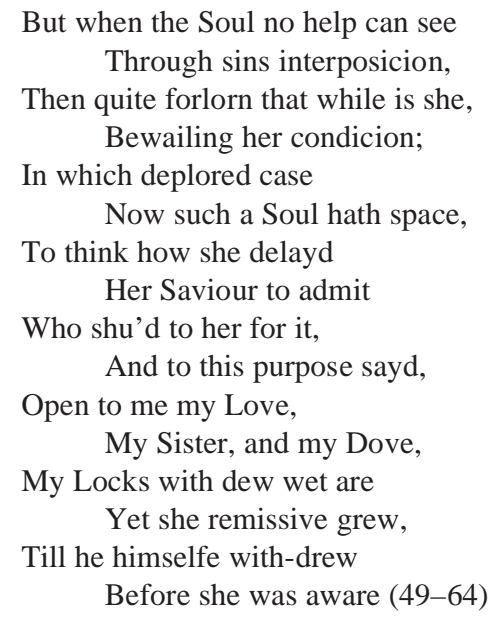

The remembrance, however, of tasting "how sweet he is, / And smelling his perfumes" (65-66) brings the devout back to a longing for God. Grace brought by faith will heal the soul and "[t]hen he will his beloved shew / The reason wherefore she / Is seated in a place so low, / Not from all troubles free" (129-132). The despair will be turned to surety because "Such need not pine with cares / Seeing all things are theirs, / If they are Christs indeed" (139-41). 
This state of rest or comfort as the goal of the devout is, as Ann Hurley states, "the essential human truth which Collins seeks to convey to her readers" in the songs. ${ }^{32}$ Collins reminds her readers that the way to obtain this rest is to dwell in the intimate presence of God which is available to them in their private devotions:

So that their Soules which are so blessed

His sacred presence to enjoy,

Can never be so much distressed

But consolacion find they may.

Having a hiding place secure,

And covert from the stormy wind,

And streames of water perfect pure

To vivify and cheare the mind.

(“A Song exciting to spirituall Alacrity," 17-24).

Though she, the religious devout, may "feel the want of outward things/ Their heavenly meditacions, comfort brings" ("The Second Meditacion," 41-2). Throughout her devotional poetry, Collins calmly weighs the balance of outwardly bodily cares, inward temptations, and sins with the joy, safety, and love of God. Always the presence of God triumphs over the sinful world. Bleakness, melancholy, and pain exist, but the word of God outlasts them all and provides "Internall Peace and Consolacion" ("Another Song," 12).

Elaine Hobby reads Collins's poetry as showing "that the poet, the Christian woman, having suffered greatly in the world from conflict and physical constraints, has found the wisdom to willingly abandon worldly concerns and fence herself into a narrow domain which allows, in practice, greater freedom." 33 Although Collins advises abandonment of the vanities of the world, she knows very well that the devout cannot rid herself totally of the world's problems and corruptions while on earth. This is why her poetry maps the reassurance given by the sustaining grace of God. Collins withdraws into private devotion for solace, but she does not isolate herself. Her time in retreat becomes a way of understanding the world around her. It is in a relationship with Christ that the devout finds healing and rest from the fragmentation and tedium of the sinful world; but she still lives within the world. She lives within it as one wrought in faith, a self ever at rest in God.

The poetry of Eliza's Babes also depicts a self constituted through faith and the word of God. The tone of this work falls between Collins's often cerebral celebration of Divine Love and the soaring mysticism of More. As Eliza's poems range over topics political, familial, and individual, they stage a reconciliation between her longing to reside in heaven and her mortality which physically anchors her to earth. Consistently in her 
poetry, heaven emerges as a site where she desires to live, where the soul visits in meditation with God, and where the soul forms the self. The poem "To my Sister S.S." provides one example of the beauty and wonder the devout finds in heaven. The poem which immediately follows, "The Vision," portrays Eliza's angst at not being able wholly to reside there: "Why from celestial bliss, did you / Draw me? these meaner things to view" $(1-2)$.

The location of her physical body causes a disruption in Eliza's longing for fulfillment. Eliza reconciles this dislocation through her union with God. In "My Satisfaction" she asserts "For with the eye of faith I see / My selfe sweet Prince, as I'me in thee: / And with thee I doe live above, / Because we live where we doe love" (9-12). The disruption caused by the either/or location of heaven and earth becomes a both/and locus through the devout's relationship with God. This union provides both the place and the person through which the subject is constituted. In the embrace of the Divine Lover, Eliza's reality encompasses heaven and earth, her transformed soul and her corrupt body.

This union with God also authorizes an identity for Eliza apart from one given to her by societal norms. She celebrates God's "abundant mercy, to me, in giving me a minde, so contrary to the most" (E6v). It is "contrary to the most" in that she does not seek the vanities of the world. However, her contrariness can also be seen in her desire not to marry, not to have babies, and not to have the tribulations common to most females. Her children are her poems, birthed in the closet of her heart where she spends time with God. Even when she does marry, she sees it as part of a divine plan. As Semler argues, Eliza's poems on marriage reveal her "reconciliation to the idea of earthly marriage as a devotional partnership which only serves to strengthen the prior and superior marriage of election in Christ." 34

More's union with the Divine Lover is not a partnership, but an absorption of the devout. In her poetry we find desire expressed as a flowing river of yearning and satiation. Like Collins and Eliza, she places herself in the role of the beloved sinner who seeks the face of her "Spouse Divine." More's poetry describes a longing to be continuously in the presence of God. The world as a "dark vayl" provides the boundary to the numinous world of heaven, creating the tension in the drama of the devout, sin, and the Divine Lover. In "Magnes Amoris Amor," the poem which heads the prose meditations through which her other poems are scattered, More introduces herself and her founding desire. ${ }^{35}$ She is the grandchild of the "Renowned More" (1) and it is as the lover of God that she sings to her "Spouse Divine": 
Mirrour of Beauty in Whose Face

The essence lives of every Grace!

True lustre dwels in they [sic] Sole Spheare

Those glimmerings that sometimes appeare

In this dark vayl, this gloomy night

Are shadows tipt with glow-

worm light,

Shew me thy radiant parts above,

Where angels unconsumed move

Where amorous fire, maintaines

their lives,

As man by breathing Air, survives.

But if perchance the mortal eye,

That views Thy dazzling looks must dye

With blindfaith heer ile kis

them and desire

To feele the heat, before I see the fire (11-28).

More desires the completeness of God which is signaled in this poem as the "sole spheare" and as the holder of the "essence" of every grace. In this world, the "lustre" of God comes through as "shadows tipt with glow- / worm light." The law barring her sight is related to those "amorous fires" which sustain angels as air does man. These "amorous fires" emanate from the "radiant parts" of God and would kill the mortal who sees them. More desires what will kill her. She longs to exist in that Other state. More metaphorically blinds herself through the assumption of "blindfaith," exchanging ocular sense for one of touch. She may not see God's "dazzling looks" because they are blinding. Through blindfaith she will "kis/ Them and desire / To feele the heat before I see the fire." Nearness substitutes for observation. Her desire transforms into affect as defined by Julia Kristeva, who differentiates between desire and affect as follows: "desire, as we shall see, emphasizes the lack, whereas affect, while acknowledging the latter, gives greater importance to the movement toward the other and to mutual attraction." 36 More's symbolic blinding modifies the construction of self in desire: she does not enter the symbolic, or become a subject with a fragmented knowledge of self, by the threat of castration. More blinds herself through faith to attain her desire, and does not maim herself as the punishment of transgression. Her action allows her to obtain Christ, the object of her desire, and to find bliss.

Even as More finds satiation, desire spurs her to want more. "Our Hearts are Restless ..." opens with an insatiable longing and languishing:

All things, desires, and loves are vaine,

but only that which tends

To God alone, our chiefest good, 
and all things ells transcends.

My soul therefore by this sweet Love

shall day, and night aspire,

And rest in God (all things above)

my Love, and lifes desire.

And while I live, ile never cease

to languish for his Love (1-10).

The boundary drawn between heaven and earth remains intact. The ensuing lines of the poem, however, reveal the boundary's permeability and the union of God and sinner through Love. More asks, "For since I am not where I love, / how can I comfort find, / But only in the song of Love, / by Love to me asign'd?" (13-16). She aspires to continue looking for the place and person of her love to find her self. Resolution comes as she realizes that "he is in thy mind! /To him relation thou maist have, / as often thou goes / Into the closett of thy hart, / thy griefs for to disclose" (44- 48). In the withdrawal of privacy to an inner space, the "closett of thy hart," the speaker may retreat to be comforted and filled with joy. She may have ready conference with the desired one through "humble Prayer" (53) and contemplation, the practices of private devotion. Though separated from heaven by her mortal state, she nonetheless finds access to it through the person of Christ who dwells within her.

The fusion of lover and beloved through Love becomes a swimming in desire. More writes, "O lett us, therefor love my God, / for Love pertains to him, / And lett our soules seek nothing ells/ but in this Love to swim" (121-124). In psychoanalytic theory this fulfillment of desire has been associated with the pre-oedipal stage, before the entrance of the child into the position of a subject in language and culture. This stage cannot be rediscovered under the law-of-the father. More's poetry changes the psychoanalytic drama where the subject position is gained through repression, rejection, and assumption of the law-of-the-father to one of gaining a subject position through accepting the sacrificed body of Christ. In these dynamics, desire changes from being predicated on the constitutive lack of language to an image of plenitude. Lack, or acknowledgment of desire, lets the devout into completeness. Desire becomes a fluidity, a longing absorbed by love:

O lett us, therefor, love my God, for Love pertains to him,

And lett our soules seek nothing ells but in this Love to swim,

Till we be absorpt by his sweet Love return from whom we came,

Where we shall melt into that Love, 
which joyeth me to name.

And never can I it too much speak of, or it desire

Since that my God, who's love itselfe, doth only Love require (121-32).

Speaking and desiring thus evolve from the absorption and satiation of love. Lack may be the harbinger of desire, but desire builds upon communion.

From this communion comes the poetry of Collins, More, and Eliza. The metaphoric and metonymic images of inwardness seed the writings of More, Collins, and Eliza to provide representations of how the female devout images private devotion and the self within this space. Through these representations the female religious devout registers her cultural imprint beyond the confines of private devotion, even as these public writings are engendered from within the prayer closet. For Collins, the self becomes a "sound mind," a discerning practitioner of religious thought who can write about matters of theology in poetic form. Eliza portrays the communion between God and devout as one where heaven and earth merge. The space of private devotion authorizes a self with a mind "contrary to most." Finally, More provides the portrait of a self dissolved in Love. She shows the permeability of boundaries in the images of her poetry. Though male writers may have sought to prescribe a confining way of knowing and understanding God for female devouts, the three writers studied here show communion with the Divine Other as a productive and at times liberating relationship for women.

Columbia Union College

\section{Notes}

1. Daniel Featley, Ancilla Pietatis, or the hand-maid to private devotion (London, 1633), sig. A2.

2. Featley, Ancilla Pietatis, sig. $\mathrm{B}^{\mathrm{v}}-\mathrm{B} 2$.

3. Peter Stallybrass, "Patriarchal Territories: The Body Enclosed," Rewriting the Renaissance: The Discourses of Sexual Difference in Early Modern England, eds. Margaret W. Ferguson, Maureen Quilligan, and Nancy J. Vickers (Chicago: U of Chicago P, 1986), p. 127.

4. See Gail Paster, The Body Embarrassed: Drama and the Disciplines of Shame in Early Modern England (Ithaca: Cornell, 1993).

5. See Caroline Walker Bynum, Fragmentation and Redemption: Essays on Gender and the Human Body in Medieval Religion (New York: Zone, 1991).

6. Pliny, Pliny Natural history, with an English translation in ten volumes, v. 6, ed. and trans. W.H.S. Jones (Cambridge: Harvard U, 1951), p. 237. 
7. Featley, Ancilla Pietatis, sig. B4v-B5.

8. Louis L. Martz, ed., "Prayer (1)," George Herbert and Henry Vaughan, The Oxford Authors (New York: Oxford UP, 1986), line 3.

9. Eliza's Babes or The Virgin's Offering (London, 1652; Wing E526, Early English Books 1641-1700, UMI Reel 142).

10. Sidney Gottlieb, ed., Introduction, an Collins divine Songs and Meditacions, Medieval \& Renaissance Texts \& Studies, v. 161 (Tempe, Az: Medieval \& Renaissance Texts \& Studies, 1996), p. xiii.

11. Richard Rambuss, Closet Devotions (Durham: Duke UP, 1998), p. 109.

12. Rambuss, p. 109.

13. Retha Warnicke, "Private and Public: The Boundaries of Women's Lives in Early Stuart England," Privileging Gender in Early Modern England, ed. Jean R. Brink, vol. 23 of Sixteenth Century Essays and Studies (Ann Arbor, MI: Edwards Brothers, 1993), p. 125.

14. Georgianna Ziegler, "My Lady's Chamber: Female Space, Female Chastity in Shakespeare," Textual Practice 4 (1990), p. 87.

15. See Ziegler, "My Lady's Chamber," pp. 73-90.

16. Richard Braithwait, The English Gentlewoman, London 1631, The English Experiences Its Record in Early Printed Books Published in Facsimile n.215 (Amsterdam, NY: De Capo P., 1970), p. 49.

17. Braithwait, The English Gentlewoman, p. 48.

18. See Dorothy Latz, “The Mystical Poetry of Dame Gertrude More,” Mystics Quarterly 16.2 (1990), pp. 66-82.

19. Gottlieb, "Introduction," pp. xvii-xviii.

20. L.E. Semler, "The Protestant Birth Ethic: Aesthetic, Political, and Religious Contexts for Eliza's Babes (1652)”, English Literary Renaissance 30.3 (2000), p. 445.

21. Michel Foucault, "Of Other Spaces," Diacritics: A Review of Contemporary Criticism, 161 (1986), p. 24.

22. See Horton Davies, Worship and Theology in England from Andrewes to Baxter and Fox, 1603-1690, vol.2 (Princeton: Princeton UP, 1975).

23. See Michael Schoenfeldt, Prayer and Power: George Herbert and Renaissance Courtship (Chicago: U of Chicago, 1991); Richard Strier, Love Known: Theology and Experience in George Herbert's Poetry (Chicago: U of Chicago, 1983); Rambuss, Closet Devotions.

24. Schoenfeldt, Prayer and Power, p. 262.

25. Schoenfeldt, Prayer and Power, p. 263.

26. See Anne Ferry, The "Inward Language": Sonnets of Wyatt, Sidney, Shakespeare, Donne (Chicago: U of Chicago P, 1983), pp. 215-250.

27. Schoenfeldt, Prayer and Power, p. 249.

28. See Jacques Lacan, "The Function and field of speech and language in psychoanalysis," in Écrits: A Selection, trans. Alan Sheridan (New York: Norton, 1977), pp. 30-113; and Elisabeth Grosz, Jacques Lacan: A feminist introduction (London: Routledge, 1990), pp. 50-81 for a discussion on the role of the symbolic in subjectivity. 
29. Grosz, Jacques Lacan, p. 71.

30. Aemilia Lanyer, "Salve Deus Rex Judaeorum," The Poems of Aemilia Lanyer: Salve Deus Rex Judaeorum, ed. Susanne Woods (New York: Oxford UP, 1993), line 1258.

31. Semler, "The Protestant Birth Ethic", p. 448.

32. Ann Hurley, "An Collins: The Tradition of the Religious Lyric, Modified or Corrected?" in Discovering and (Re)Covering the Seventeenth Century Religious Lyric, eds. Eugene R. Cunnar \& Jeffrey Johnson (Pittsburgh: Duquesne UP, 2001), p. 241.

33. Elaine Hobby, Virtue of Necessity: English Women's Writings 1649-88 (Ann Arbor: U of Michigan, 1989), p. 62.

34. Semler, "The Protestant Birth Ethic," p. 448

35. Dorothy L. Latz, "Glow Worm Light" Writings of $17^{\text {th }}$ Century English Recusant Women from Original Manuscripts (Salzburg: Institut für Anglistik Und Amerikanistik, 1989). All subsequent references will be made parenthetically.

36. Julia Kristeva, Tales of Love, trans. Leon S. Roudiez (New York: Columbia UP, 1997), p. 155. 